\title{
Effects of Exercise Training on Mobilization and Functional Activity of Blood-Derived Progenitor Cells in Patients with ACUTE MYOCARDiAL INFARCTION
}

\author{
M. Brehm¹ ${ }^{1}$, F. Picard ${ }^{1}$, P. Ebner ${ }^{1}$, G. Turan ${ }^{1}$, E. Bölke ${ }^{3}$, M. Köstering ${ }^{1}$, P. Schüller ${ }^{1}$, T. Fleissner ${ }^{1}$, \\ D. Ilousis ${ }^{1}$, K. Augusta ${ }^{2}$, M. Peiper ${ }^{4}$, Ch. Schannwell ${ }^{1}$, B. E. Strauer ${ }^{1}$ \\ ${ }^{1}$ Department of Medicine, Division of Cardiology, Pneumology and Angiology, \\ ${ }^{2}$ Rehabilitation Centre of Cardiology, \\ ${ }^{3}$ Department of Radiooncolgy, \\ ${ }^{4}$ Department of Surgery, \\ Heinrich-Heine University of Düsseldorf, Germany
}

\begin{abstract}
Background: The aim of the present study was to determine whether regular exercise training (ET) is effective at promoting the mobilization of CPCs and improving their functional activity in patients with recently acquired myocardial infarction (STEMI). Regular physical training has been shown to improve myocardial perfusion and cardiovascular function. This may be related in part to a mobilization of bone marrow-derived circulating progenitor cells (CPCs) as well as an enhanced vascularisation.

Methods: 37 patients with STEMI were randomly assigned to an ET group or a non-ET group (controls). Two weeks after STEMI, three weeks after regular ET and three months after ET, BNP levels, exercise echocardiography and exercise spiroergometry were evaluated. The number of $\mathrm{CD} 34^{+} / \mathrm{CD} 45^{+}$and CD $133^{+} / \mathrm{CD} 45^{+}$CPCs was measured by flow cytometry analysis. The migration capacity of the CPCs was determined with a boyden chamber and the clonogenic capacity by CFU-assay.

Results: In the ET-group the number and migration capacity of CPCs increased significantly after regular exercise training. The BNP level decreased significantly from $121 \pm 94$ to $75 \pm 47 \mathrm{pg} / \mathrm{ml}(\mathrm{p}<0.001)$ after the ET period, the left ventricular ejection fraction raised in parallel at peak exercise, and the cardiorespiratory condition improved as demonstrated by an increase of $\mathrm{VO}_{2} \max$ (from $1641 \pm 522$ to $1842 \pm 724 \mathrm{ml} / \mathrm{min}$, $\mathrm{p}<0.02)$. These three effects persist till three months after the ET period.

Conclusions: Regular physical activity appears to predispose the mobilization and enhanced functional activity of CPCs, a phenomenon which might lead to an improved cardiac function in patients with recently acquired acute myocardial infarction.
\end{abstract}

Key words: Exercise training, Cytokines, Progenitor Cells, Myocardial Infarction, Rehabilitation

\section{INTRODUCTION}

Regular physical training reduces the incidence of cardiovascular events such as coronary heart disease, reinfarction and cardiovascular mortality [1-4]. In addition to a reduction of cardiovascular risk factors such as hypertension, diabetes mellitus and obesity, there is also an increased regression of coronary stenosis. Clinical studies have shown that physical training improves myocardial perfusion and cardiovascular function in coronary artery disease $[5,6]$. This might be related to a correction of endothelial dysfunction as well as a promotion of antiinflammatory mechanisms [7]. The enhanced expression of eNOS and VEGF (vascular endothelial growth factor) might improve the mobilization of bone marrow-derived circulating progenitor cells (CPCs) into peripheral blood and enhance the process of vasculogenesis [8-10]. Tissue ischemia was found to mobilize bone marrow-derived CPCs into the peripheral blood and contribute to neovascularisation in an animal model [11]. Human bone marrow-derived CPCs significantly increase in patients with acute myocardial infarction [12] and are able to differentiate into cardiac myocytes, endothelial cells and smooth muscle cells [13].

In coronary artery disease, however, the quantity and function of CPCs are reduced, a phenomenon that might depend on various cardiovascular risk factors such as age, gender, smoking, diabetes mellitus and hypertension. Vasa et al. were able to demonstrate a reduced amount of blood-derived CPCs in the peripheral blood of patients with coronary artery disease in a manner that depended on the number of cardiovascular risk factors [14].

Despite the reduced quantity and restricted functionality of CPCs, Hambrecht and coworkers found that regular exercise training in patients with chronic coronary artery disease can improve cardiac function. An enhanced mobilization of progenitor cells has also 
been revealed following repeated exercise induced myocardial ischemia, as well as an enhanced expression of angiogenetic cytokines such as VEGF. This increases the mobilisation of progenitor cells from the bone marrow into the peripheral blood and probably leads on the one hand to an intensified repair of vascular lesions in the coronary vasculature and on the other hand to a neovascularisation within the heart muscle [15].

The aim of our prospective study was to investigate the effect of regular exercise training over three weeks (rehabilitation program) on physical capacity, cardiac performance and the mobilisation and function of CPCs in patients with an acute myocardial infarction (STEMI). For this purpose we determined the quantity and function of CPCs in peripheral blood isolated from STEMI patients at three different time points: $\left(t_{0}\right)$ bevor intervention ( 2 weeks after acute myocardial infarction) $\left(t_{1}\right)$ three weeks after intervention start (five weeks after acute myocardial infarction) and $\left(t_{2}\right)$ three months after rehabilitation (17 weeks after acute myocardial infarction).

\section{PATIENTS AND METHODS}

Study protocol: Patients with a documented ST-elevation myocardial infarction (STEMI), onset of pain up to $12 \mathrm{~h}$, a left ventricular ejection fraction below $<60 \%$ and under the age of 75 years were enrolled in this prospective study between February 2005 and August 2006. Exclusion criteria included STEMI, significant valvular heart disease, cardiogenic shock, renal failure, anemia, orthopedics or other conditions that prohibited participation in the exercise training. None of the patients had a history of myocardial infarction.
All patients were treated immediately during the acute phase of the infarction with aspirin, clopidogrel and tirofiban. Subsequently coronary angiography was performed and the occluded infarct-related coronary artery was recanalized. One week after myocardial infarction all patients were randomly assigned to the exercise or non-exercise training group (Fig. 1). For therapeutic reasons more patients were randomized to the exercise training group (rehabilitation) and so we chose a 2:1 randomization. At discharge all patients received aspirin, clopidogrel, angiotensin-converting enzyme inhibitors or angiotensin-1 receptor antagonists, beta-blockers and statins.

Follow-up visits were performed at 2 weeks $\left(t_{0}\right)$, five weeks $\left(t_{1}\right)$ and 17 weeks $\left(t_{2}\right)$ and included clinical status, laboratory examinations, ECG, exercise echocardiography, spiroergometry, adverse events and medications. The protocol for this study was approved by the local Ethics Committee of the Heinrich- Heine University in Düsseldorf.

Study objectives: The primary end points were changes of global cardiac function using exercise echocardiography from $t_{0}$ ( 2 weeks after acute PCI) to $t_{1}$ and $t_{2}$ (five and 17 weeks) of follow-up. Global function was determined by left ventricular ejection fraction (EF). Secondary end points comprised changes of oxygen consumption per unit time $\left(\mathrm{VO}_{2}\right)$ using spiroergometry from $\mathrm{t}_{0}$ (2 weeks after acute AMI) to five and 17 weeks of follow-up. Changes of mobilized stem cells $\left(\mathrm{CD} 34 / \mathrm{CD} 45^{+}, \mathrm{CD} 133 / \mathrm{CD} 45^{+}\right)$, changes of migration capacity of the mononuclear cells and changes of their clonogenic potential (CFU-assays) were analyzed.

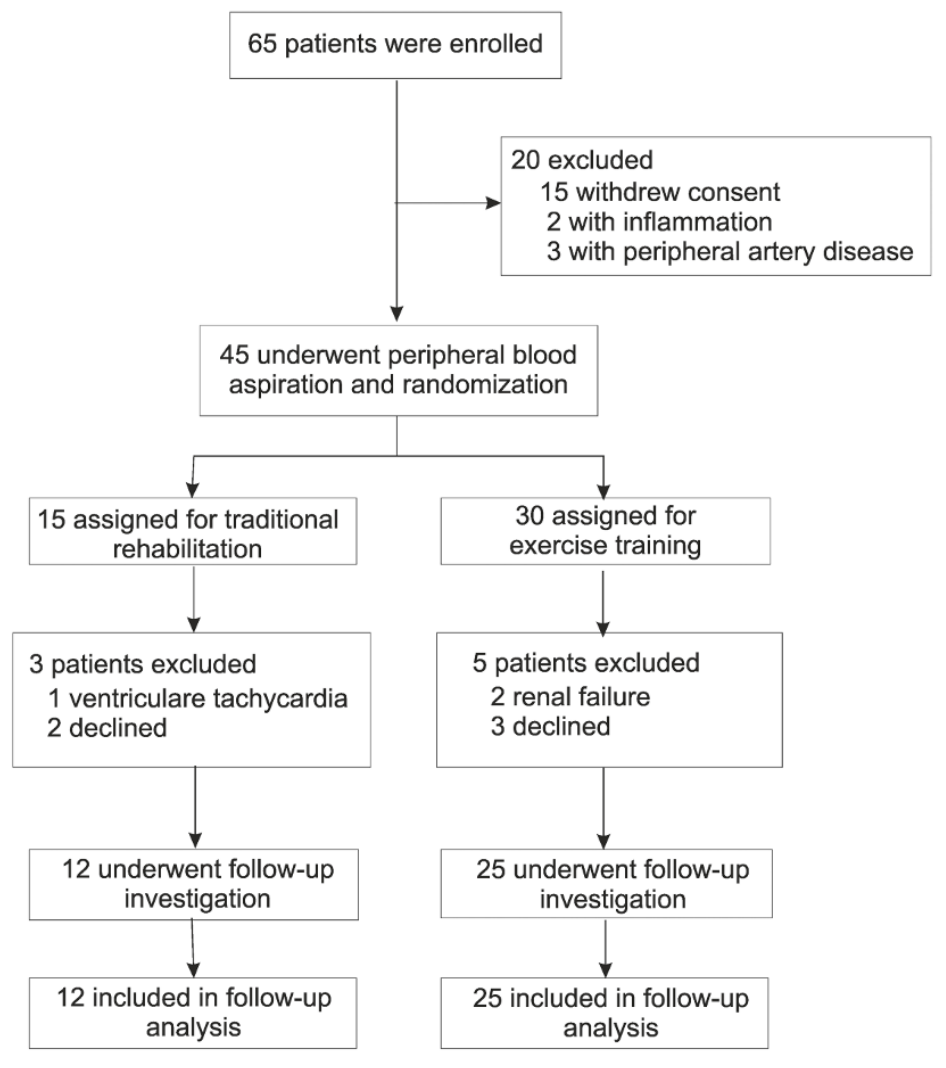

Fig. 1. Enrollment and outcomes. 


\section{Exercise training group}
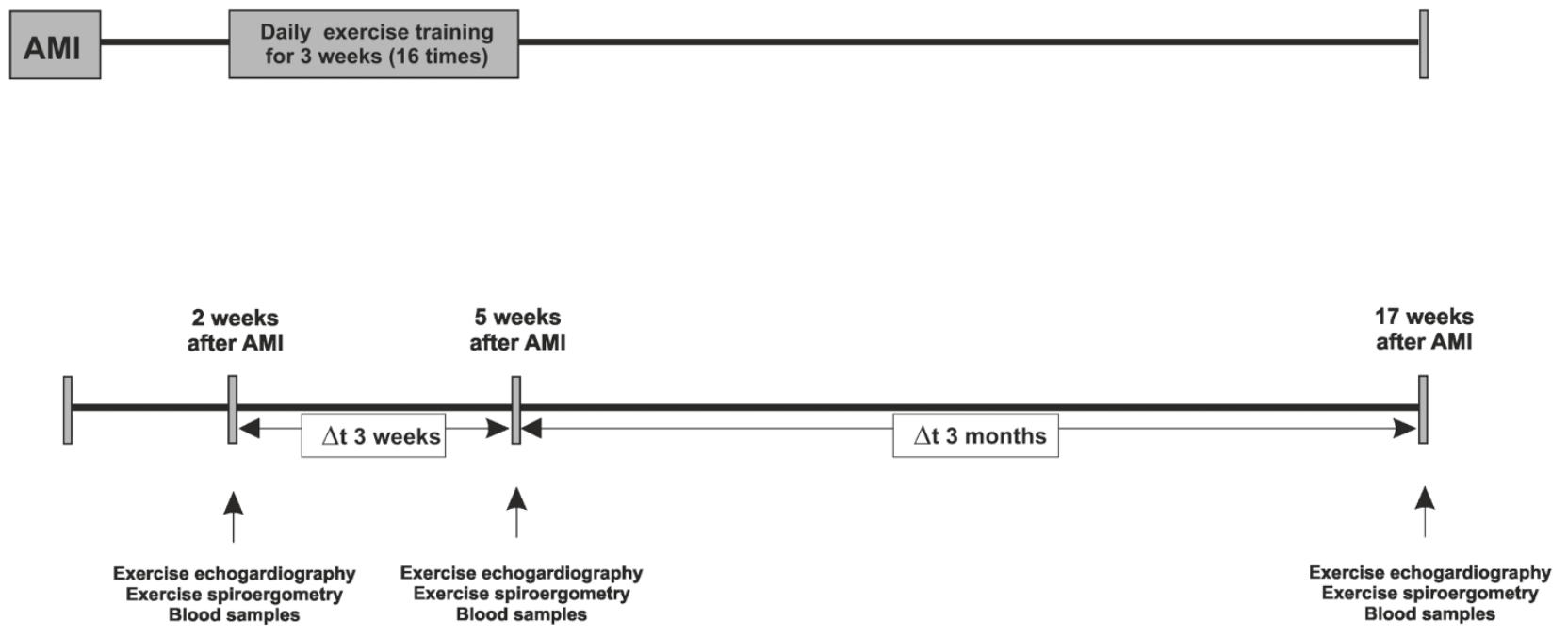

\section{Control group}

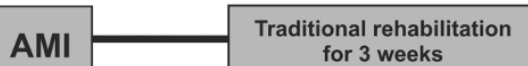

Fig. 2. Flow chart of the prospective controled clinical study. AMI, acute myocardial infarction.

Maximal exercise training test: A maximal exercise training (ET) test was performed on a calibrated, electronically braked bicycle ergometer in an upright position. It was performed once daily, on five days a week, and for three weeks in total (15 times maximal exercise training, Fig. 2).

According to Gysan et al. and Schönstedt et al., we chose an ambulatory shortterm endurance training, demonstrating good compliance by the patients and a beneficial outcome [16, 17]. ECG tracing and blood pressure readings were obtained every two minutes. Workload was increased progressively every 2 minutes at steps of $25 \mathrm{~W}$, beginning at $25 \mathrm{~W}$. Myocardial ischemia was confirmed by the presence of typical angina pectoris or a significant exercise-induced ST-segment depression ( $>0.1 \mathrm{mV}$ descending or horizontal). Exercise was terminated when patients experienced progressive chest pain, physical exhaustion, or when a 3-mm horizontal ST-segment depression was reached.

Exercise echocardiography: Echocardiographic images were obtained in the parasternal long- and short axis, and apical 2- and 4-chamber views using commercially available equipment with a $2.5-\mathrm{MHz}$ transducer rate of $30 \mathrm{frames} / \mathrm{s}$. These images were recorded in quadscreen cine loop format before and within 90 seconds after treadmill exercise testing. Enddiastolic and endsystolic diameter of the left ventricle at rest and after exercise was visually interpreted by the consensus of at least two experienced physician echocardiographers unaware of the results of the left ventricular angiogram and the coronary angiography. The digital quadscreen cine loop format was reviewed for analysis of left ventricular function which was assessed by cal- culation of the enddiastolic and endsystolic volumes (Simpson formula).

Bicycle spiroergometry: After resting for 5 minutes, the patients had their arterial blood pressure measured at the right brachial artery using a sphygmomanometer. A 12-lead electrocardiogram was recorded, and resting heart rate (HR) was calculated from the R-R interval. Each subject underwent maximal exercise testing on a computer-driven bicycle ergometer using a ramp protocol starting at $50 \mathrm{~W}$, with gradual increases of $25 \mathrm{~W}$ every 2 minutes. During the test, patients worn a tightfitting face mask connected to an Oxycon Pro spirometer. Oxygen consumption per unit time $\left(\mathrm{VO}_{2}\right)$, carbon dioxide production $\left(\mathrm{VCO}_{2}\right)$, and minute ventilation were measured on a breath-by-breath basis. Subjects were exercised to their self-determined maximal capacity or until the physician stopped the test because of symptoms such as chest pain or dizziness, potentially dangerous arrhythmias or ST-segment deviations, or marked systolic hypotension or hypertension. A respiratory exchange ratio $\left(\mathrm{VCO}_{2} / \mathrm{VO}_{2}\right)>1$ was taken to indicate maximal effort. Maximum oxygen consumption was defined as the highest $\mathrm{VO}_{2}$ obtained at the end of the test and is expressed in $\mathrm{ml} / \mathrm{min}$ and $\mathrm{ml} / \mathrm{min}$ per $\mathrm{kg}$.

Collection of venous blood samples: On the day before the exercise training program starts $\left(\mathrm{t}_{0}\right)$, one day after the exercise training program ends $\left(t_{1}=\right.$ three weeks, 15 times exercise training tests) and three months after the exercise training program $\left(t_{2}\right)$ venous blood samples were taken in the morning from fasting patients. FACS analysis, isolations of circulating progenitor 
cells for migration and colony-forming-unit assay were performed in all samples.

From the control patients with no exercise training venous blood samples were also taken at matched time points (Fig. 2).

Measurement of brain natriuretic peptide (BNP) in peripheral blood: In order to determine BNP levels, peripheral blood was taken at the same three time points as descriped above. Whole blood samples were used from all patients and BNP was measured using TriageMeter Plus (Biosite).

Isolation and cultivation of circulating progenitor cells: $20 \mathrm{ml}$ peripheral venous blood was taken from each patient at the three time points, as described above. Blood was taken using a BD Vacutainer CPT'TM sys- tem containing a citrate anticoagulant with Ficoll Hypaque density fluid and a polyester gel barrier. Blood samples were centrifugated for $20 \mathrm{~min}$. at $3.000 \mathrm{rpm}$ (rounds per minute) at room temperature. The mononuclear cells (MNCs) were resuspended by inverting the tube and the entire content above the gel was transferred into a separate tube. After adding phosphate buffered saline (PBS) the MNCs were centrifugated for $10 \mathrm{~min}$. with $2.300 \mathrm{rpm}$. Afterwards ammonium chloride was added for $10 \mathrm{~min}$. to accomplish the lysis of all red blood cells. After two washing steps with PBS mononuclear cells were resuspended in $1 \mathrm{ml}$ EBM2-medium (Cell systems). The cell number was determined in a Neubauer chamber.

Flow cytometry analysis: Two colour flow cytometry assays were performed using an EPICS XL flow cy-
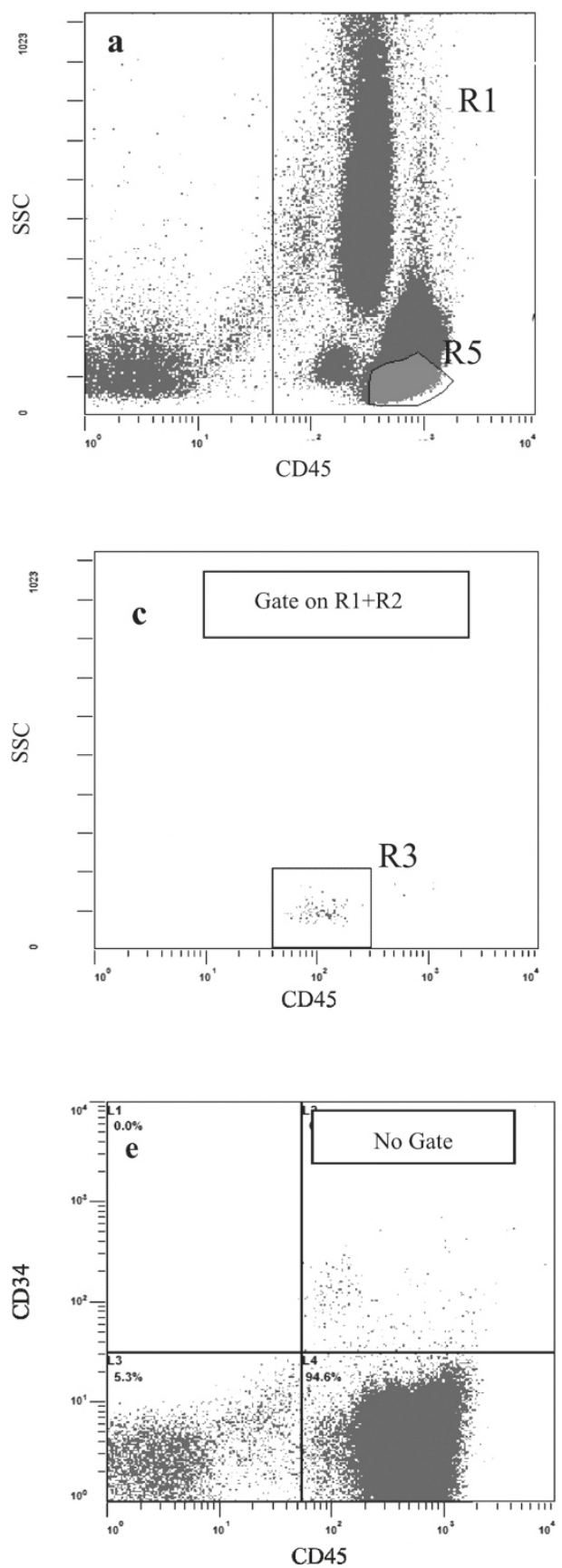
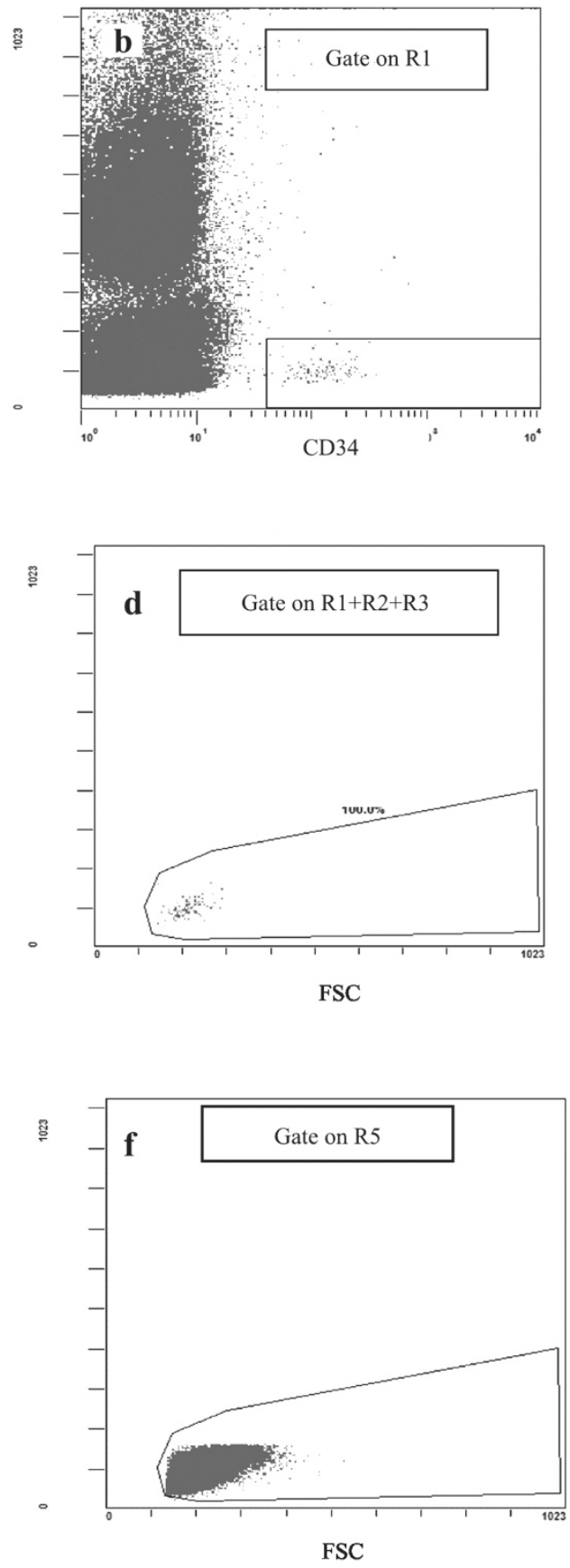

Fig. 3. Representative flow cytometry gating strategy for $\mathrm{CD} 45^{+} / \mathrm{CD} 34^{+}$(Fig. 3a-f) blood-derived circulating progenitor cells, in patients with acute myocardial infarction. 


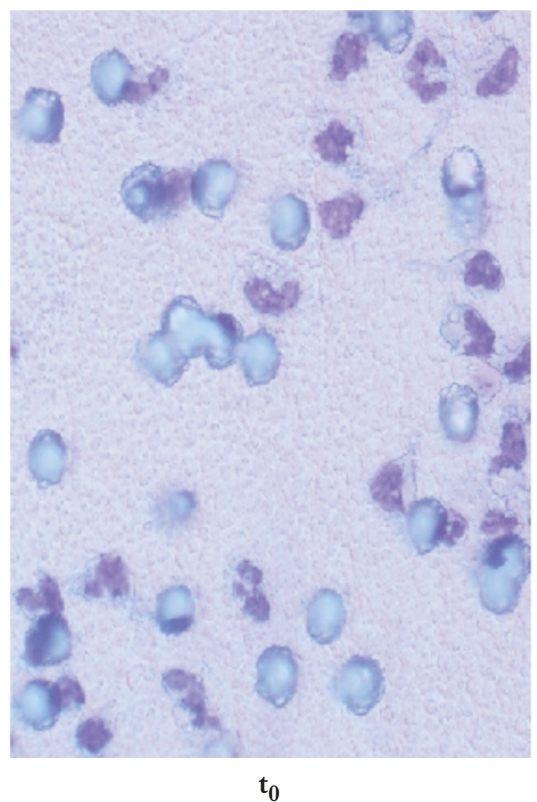

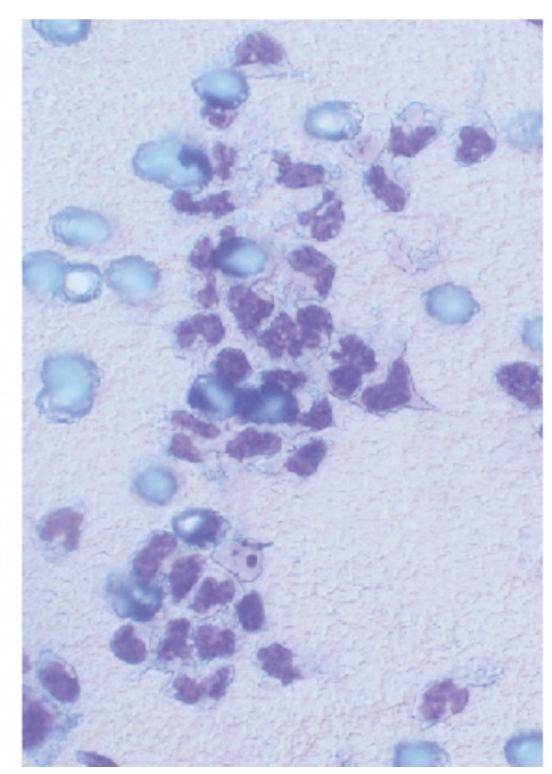

$t_{1}$

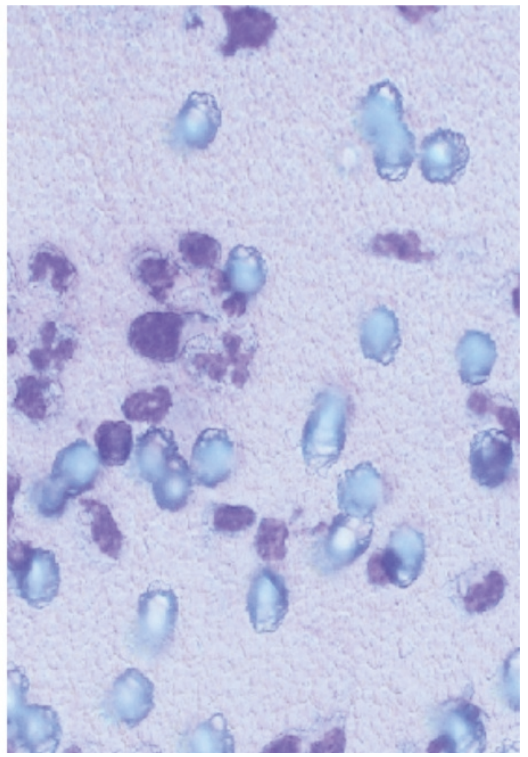

$\mathbf{t}_{2}$

Fig. 4. Representative photos of a migration assay from an AMI patient with exercise training; before exercise training $\left(\mathrm{t}_{0}\right)$, after exercise training $\left(t_{1}\right)$ and 3 months after exercise training $\left(t_{2}\right)$. Cells were evaluated $24 \mathrm{~h}$ after seeding $3 \times 10^{6} \mathrm{MNCs}$ per ml in the upper compartiment of a boyden chamber. The assay showed a significant increase of migrated cells after the exercise training.

tometer (Beckman Coulter / Immunotech, Roissy CDG, France) and Expo 32 data acquisition software (Beckman Coulter / Immunotech). The instrument was calibrated using beads (Beckman Coulter / Immunotech) according to the manufacturer's instructions. For erythrocyte lysis, peripheral blood samples were diluted in $15 \mathrm{ml}$ bicarbonatebuffered ammonium chloride solution $\left(0.15 \mathrm{M} \mathrm{NH} \mathrm{NH}_{4} \mathrm{CL}, 0.01 \mathrm{M} \mathrm{NaHCO}\right.$, $1.0 \mathrm{mM}$ EDTA) for 15 minutes at room temperature. The cells were centrifuged and resuspended in $500 \mu \mathrm{l}$ pH 7.2 phosphate-buffered saline (PBS) (lyse-nowash, technique). In brief, $100 \mu$ l of white-blood cell sample were incubated with $10 \mu$ l of FITC-conjugated anti- CD45 (BD) and 10 $\mu$ l of phyocerythrin (PE)-conjugated anti-CD34 (BD) or anti-CD133 (BD) for 20 minutes at $4^{\circ} \mathrm{C}$. All experiments included samples incubated with an isotype control PE-labelled IgG1 (Beckman Coulter) as a negative control for nonspecific binding. All samples were run in duplicate. Samples were stored on ice in the dark and analyzed within two hours. The ISHAGE sequential gating strategy[18] exploits the fact that blast cells can be identified from their dim CD45 expression and low sidescatter (SSC)[19]. Figure 3 illustrates an example of our experiments using the gating strategy for CD34 analysis (Fig. 3a-f).

Migration assay: Analysis of cell migration was performed by seeding $1 \times 10^{6}$ MNCs per $\mathrm{ml}$ in the top compartment of a boyden chamber (Fig. 4). The bottom compartment contained either only EBM-2 medium (supplemented with $0.1 \% \mathrm{BSA}$ ) or $100 \mathrm{ng} / \mathrm{ml}$ stromal cell derived factor-1 (SDF-1) or $200 \mathrm{ng} / \mathrm{ml} \mathrm{VEGF}$ (vascular endothelial growth factor) in EBM2-medium (supplemented with $0.1 \% \mathrm{BSA}$ ). Cells were allowed to migrate for $24 \mathrm{~h}$ at $37^{\circ} \mathrm{C}$ in humidified atmosphere. The migrated cells were stained using a Diff-Quick
Staining Kit (Dade Behringer) and then counted by two independent investigators.

Colony-forming unit assay: 1 x $10^{5} \mathrm{MNCs}$ per $\mathrm{ml}$ were seeded in Methocult GF H4434 (Stemcell Technologies). Culture dishes were seeded with $1 \mathrm{ml}$ cell suspension and then incubated at $37^{\circ} \mathrm{C}$ in $5 \% \quad \mathrm{CO}_{2}$. Colony-forming-unit erythroid (CFU-E) and CFUgranulocyte/ macrophage (CFU-GM) were evaluated 14 days after seeding, using an inverted microscope. The different clusters in the CFU assays were distinguished by their characteristic morphology and illumination by using an inverted microscope. No staining or immunostaining was performed. CFU-eryhtroid clusters showed small clusters and emitted a red to brownish colour, whereas CFU-granulocyte/macrophage clusters presented flat colonies consisting of translucent cells. CFU assays were quantified by counting the clusters by two independent investigators.

Statistics: Variables are presented as means \pm standard deviation (SD), depicted in the text and figures. Categorical variables were compared with use of the chisquare test or Fischer's exact test. Statistical comparisons between initial and follow-up data were performed in a nonparametric paired fashion using the Wilcoxon signed-rank test. The nonparametric MannWhitney U test was used for intergroup comparisons. Statistical significance was assumed if $\mathrm{p}$ was $<0.05$. All probability values are 2 -tailed. Statistical analysis was performed using SPSS (version 12.0).

\section{RESULTS}

Patient characteristics: The baseline characteristics were comparable in both groups (Table 1). All patients suffered from an occlusion (Thrombolysis in Myocar- 
Table 1. Characteristics of patients.

\begin{tabular}{|c|c|c|c|}
\hline & Exercise Training after AMI & Control- Patients with AMI & $\mathrm{p}$ \\
\hline \multicolumn{4}{|l|}{ Characteristics } \\
\hline No. of patients & 25 & 12 & n.s. \\
\hline Gender $\mathrm{m} / \mathrm{w}$ & $21 / 4$ & $7 / 5$ & n.s. \\
\hline Age (yrs) & $60 \pm 9$ & $63 \pm 10$ & n.s. \\
\hline Body-Mass Index (kg/m2) & $27.30 \pm 2.43$ & $27.4 \pm 3.94$ & n.s. \\
\hline NYHA-classification & $2.64 \pm 0.57$ & $2.75 \pm 0.62$ & n.s. \\
\hline I/II/III/IV & $0 / 10 / 14 / 1$ & $0 / 4 / 7 / 1$ & \\
\hline BNP level, $\mathrm{pg} / \mathrm{ml}$ & $121 \pm 94$ & $127 \pm 78$ & n.s. \\
\hline \multicolumn{4}{|l|}{ Coronary angiography } \\
\hline No. of coronary vessel disease & $2.16 \pm 0.83$ & $2.5 \pm 0.71$ & n.s. \\
\hline $1 / 2 / 3$ - coronary vessel disease & $7 / 8 / 10$ & $2 / 3 / 7$ & \\
\hline \multicolumn{4}{|l|}{ Infarct-related coronary vessel } \\
\hline $\mathrm{LAD} / \mathrm{LCX} / \mathrm{RCA}$ & $10 / 7 / 8$ & $5 / 3 / 4$ & \\
\hline No. of patients with stent, $n(\%)$ & $24(96)$ & $12(100)$ & \\
\hline \multicolumn{4}{|l|}{ Risk factors, $\mathrm{n}(\%)$} \\
\hline Smoking & $10(40)$ & $5(42)$ & n.s. \\
\hline Hypercholesterolemia & $25(100)$ & $12(100)$ & n.s. \\
\hline Diabetes mellitus & $4(16)$ & $2(17)$ & n.s. \\
\hline Hypertension & $18(72)$ & $9(75)$ & n.s. \\
\hline Positive family History & $8(32)$ & $4(33)$ & n.s. \\
\hline \multicolumn{4}{|l|}{ Medication, n (\%) } \\
\hline Acetylsalicylacid & $25(100)$ & $12(100)$ & n.s. \\
\hline Clopidogrel & $24(96)$ & $12(100)$ & n.s. \\
\hline Beta-blocker & $25(100)$ & $12(100)$ & n.s. \\
\hline ACE-inhibitor or AT-1 antagonist & $25(100)$ & $11(90)$ & n.s. \\
\hline Statin & $25(100)$ & $12(100)$ & n.s. \\
\hline \multicolumn{4}{|l|}{ Labaratory parameters } \\
\hline $\mathrm{CPK}[\mathrm{U} / \mathrm{L}]$ & $1196 \pm 1463$ & $1002 \pm 1099$ & n.s. \\
\hline CPK-MB (U/L) & $189 \pm 259$ & $136 \pm 219$ & n.s. \\
\hline Troponin I (ng/ml) & $21.5 \pm 15.3$ & $12.4 \pm 9.5$ & n.s. \\
\hline $\mathrm{LDH}(\mathrm{U} / \mathrm{L})$ & $545 \pm 551$ & $319 \pm 164$ & n.s. \\
\hline $\mathrm{CRP}(\mathrm{mg} / \mathrm{dl})$ & $5.28 \pm 7.53$ & $3.98 \pm 5.41$ & n.s. \\
\hline
\end{tabular}

dial Infarction (TIMI) flow grade $0 / 1$ of 1 coronary artery resulting in extensive myocardial infarctions. Percutaneous coronary intervention was successfully achieved in all patients resulting in TIMI flow grad $2 / 3$. There was no significant difference between the exercise training group and the control group regarding cardiovascular risk factors, use of glycoprotein IIb/IIIa antagonists and current medication. $25 \mathrm{pa}-$ tients were randomly assigned to the exercise training group and 12 patients to the control group with no physical training.

Effects of exercise training on clinical parameters and BNP-levels in patients with STEMI: Patients in the exercise training group showed a significant improvement in their clinical condition after the exercise training test and three months later, as assessed by the NYHA classification (New York Heart Association).
Furthermore, the BNP-level in peripheral blood decreased significantly after the ET-program from 121 \pm 94 to $75 \pm 47 \mathrm{pg} / \mathrm{ml}(\mathrm{p}<0.001)$ and remained reduced three months thereafter at $54 \pm 42 \mathrm{pg} / \mathrm{ml}$ (Table 2). There were no significant changes in the non-exercise control group. In the exercise echocardiography we found no difference in the left ventricular ejection fraction (EF) at rest in either group over the investigated time, but at peak exercise the left ventricular ejection fraction increased after the three week-long exercise training program from $57 \pm 14$ to $60 \pm 14 \%$, and compared to the $\mathrm{EF}$ at rest (49 \pm $12 \%)$, the peak EF $(60 \pm 14 \%)$ was significantly increased $(p=0.031)$. In the spiroergometry, $\mathrm{VO}_{2} \max$ increased significantly only in the ET-group from $1641 \pm 522$ to $1842 \pm 724, \mathrm{p}=0.017$ (baseline to after exercise training) and remained stable for the three months thereafter. 
Table 2. Response to exercise training and traditionaly rehabilitation in patients with STEMI evaluated by ergometry, exercise echogardiography, exercise spiroergometry and BNP (brain natriuretic peptide).

\begin{tabular}{|c|c|c|c|c|c|c|}
\hline Clinical status & $t_{0}$ & $t_{1}$ & $\mathrm{p}^{+}$ & $t_{2}$ & $\mathrm{p}^{\#}$ & $\mathrm{p} \mathbb{S}$ \\
\hline $\begin{array}{l}\text { NYHA-classification } \\
\text { exercise training } \\
\text { controls } \\
\text { p }\end{array}$ & $\begin{array}{l}2.64 \pm 0.57 \\
2.75 \pm 0.62 \\
\text { n.s. }\end{array}$ & $\begin{array}{l}1.32 \pm 0.48 \\
2.25 \pm 0.62 \\
<0.001\end{array}$ & $\begin{array}{c}<0.001 \\
0.083\end{array}$ & $\begin{array}{l}1.52 \pm 0.51 \\
2.42 \pm 0.52 \\
\quad<0.001\end{array}$ & $\begin{array}{c}0.096 \\
\text { n.s. }\end{array}$ & $\begin{array}{c}<0.001 \\
\text { n.s. }\end{array}$ \\
\hline $\begin{array}{l}\text { BNP, pg } / \mathrm{ml} \\
\text { exercise training } \\
\text { controls } \\
\mathrm{p}\end{array}$ & $\begin{array}{c}121 \pm 94 \\
127 \pm 78 \\
\text { n.s. }\end{array}$ & $\begin{array}{c}75 \pm 47 \\
111 \pm 80 \\
\text { n.s. }\end{array}$ & $\begin{array}{c}<0.001 \\
\text { n.s. }\end{array}$ & $\begin{array}{c}54 \pm 42 \\
92 \pm 63 \\
0.080\end{array}$ & $\begin{array}{c}<0.001 \\
\text { n.s. }\end{array}$ & $\begin{array}{c}<0.001 \\
\text { n.s. }\end{array}$ \\
\hline $\begin{array}{l}\text { Ergometry } \\
\text { max. workload, watt } \\
\text { exercise training } \\
\text { controls } \\
\text { p }\end{array}$ & $\begin{array}{c}101 \pm 33 \\
- \\
-\end{array}$ & $\begin{array}{c}137 \pm 53 \\
- \\
-\end{array}$ & $<0.001$ & & & \\
\hline $\begin{array}{l}\text { Duration of exercise, } \text { min } \\
\text { exercise training } \\
\text { controls } \\
\text { p }\end{array}$ & $\begin{array}{l}5.68 \pm 2.03 \\
- \\
-\end{array}$ & $\begin{array}{c}7.18 \\
- \\
-\end{array}$ & 0.007 & & & \\
\hline $\begin{array}{l}\text { Exercise echocardiography } \\
\text { EF at rest, \% } \\
\text { exercise training } \\
\text { controls } \\
\text { p }\end{array}$ & $\begin{array}{l}46 \pm 12 \\
48 \pm 13 \\
\text { n.s. }\end{array}$ & $\begin{array}{l}49 \pm 12 \\
49 \pm 16 \\
\text { n.s. }\end{array}$ & $\begin{array}{c}0.028 \\
\text { n.s. }\end{array}$ & $\begin{array}{l}49 \pm 11 \\
49 \pm 12 \\
\text { n.s. }\end{array}$ & $\begin{array}{l}\text { n.s. } \\
\text { n.s. }\end{array}$ & $\begin{array}{c}0.009 \\
\text { n.s. }\end{array}$ \\
\hline $\begin{array}{l}\text { EF at peak exercise, } \% \\
\text { exercise training } \\
\text { controls } \\
\mathrm{p}\end{array}$ & $\begin{array}{l}57 \pm 14 \\
57 \pm 6 \\
\text { n.s. }\end{array}$ & $\begin{array}{c}60 \pm 14 \\
58 \pm 7 \\
\text { n.s. }\end{array}$ & $\begin{array}{l}0.031 \\
\text { n.s. }\end{array}$ & $\begin{array}{c}60 \pm 15 \\
59 \pm 8 \\
\text { n.s. }\end{array}$ & $\begin{array}{l}\text { n.s. } \\
\text { n.s. }\end{array}$ & $\begin{array}{c}0.020 \\
\text { n.s. }\end{array}$ \\
\hline $\begin{array}{l}\text { Exercise spiroergometry } \\
\text { max. workload, watt } \\
\text { exercise training } \\
\text { controls } \\
\text { p }\end{array}$ & $\begin{array}{c}123 \pm 47 \\
125 \pm 33 \\
\text { n.s. }\end{array}$ & $\begin{array}{c}140 \pm 53 \\
122 \pm 41 \\
\text { n.s. }\end{array}$ & $\begin{array}{c}0.004 \\
\text { n.s. }\end{array}$ & $\begin{array}{c}137 \pm 52 \\
131 \pm 44 \\
\text { n.s. }\end{array}$ & $\begin{array}{l}\text { n.s. } \\
\text { n.s. }\end{array}$ & $\begin{array}{c}0.011 \\
\text { n.s. }\end{array}$ \\
\hline $\begin{array}{l}\mathbf{V O}_{2} \max , \mathrm{ml} / \mathrm{min} \\
\text { exercise training } \\
\text { controls }\end{array}$ & $\begin{array}{l}1641 \pm 522 \\
1389 \pm 547\end{array}$ & $\begin{array}{l}1842 \pm 724 \\
1439 \pm 465\end{array}$ & $\begin{array}{c}0.017 \\
\text { n.s. }\end{array}$ & $\begin{array}{l}1855 \pm 695 \\
1851 \pm 429\end{array}$ & $\begin{array}{l}\text { n.s. } \\
0.050\end{array}$ & $\begin{array}{c}0.012 \\
\text { n.s. }\end{array}$ \\
\hline $\begin{array}{l}\mathrm{p} \\
\mathrm{VO}_{2} \mathrm{max} / \mathrm{kg}, \mathrm{ml} / \mathrm{min} / \mathrm{kg} \\
\text { exercise training } \\
\text { controls } \\
\mathrm{p}\end{array}$ & $\begin{array}{c}20.0 \pm 4.3 \\
17.6 \pm 5.6 \\
\text { n.s. }\end{array}$ & $\begin{array}{c}22.5 \pm 6.5 \\
17.3 \pm 4.5 \\
0.096\end{array}$ & $\begin{array}{c}0.015 \\
\text { n.s. }\end{array}$ & $\begin{array}{l}22.9 \pm 6.6 \\
21.7 \pm 5.0 \\
\text { n.s. }\end{array}$ & $\begin{array}{c}\text { n.s. } \\
0.093\end{array}$ & $\begin{array}{c}0.012 \\
\text { n.s. }\end{array}$ \\
\hline
\end{tabular}

$\mathrm{EF}=$ left ventriculare ejection fraction; $\mathrm{VO}_{2} \mathrm{max}=$ maximum oxygen consumption; $\mathrm{BNP}=$ brain natriuretic peptide; Values are mean \pm SD. $\mathrm{p}^{+}=\mathrm{t}_{0}$ vs. $\mathrm{t}_{1} ; \mathrm{p}^{\#}=\mathrm{t}_{1}$ vs. $\mathrm{t}_{2} ; \mathrm{p} \mathbb{\$}=\mathrm{t}_{0}$ vs. $\mathrm{t}_{2}$

The NYHA classification showed a significant improvement at five weeks and 17 weeks of follow-up in the exercise training compared to the controls. BNP demonstrated a relevant decrease at 17 weeks of follow-up when both groups were compared. Further, oxygen consumption per unit time per $\mathrm{kg}\left(\mathrm{VO}_{2} / \mathrm{kg}\right)$ was slightly increased in the exercise training group compared to the controls.

Effects of regular exercise training on circulating progenitor cells: FACS-analysis showed that a symptomlimited (ischemic) exercise training led to a significant and time-dependent increase from $\mathrm{t}_{0}$ ( 2 weeks after acute AMI) to five weeks of follow-up in the CD $45^{+} / \mathrm{CD} 34^{+}$CPC-fraction from $257 \pm 102$ to 302 \pm 128 cells per 1 million MNCs $(\mathrm{p}=0.022)$ and in the $\mathrm{CD}^{2} 5^{+} / \mathrm{CD} 133^{+} \mathrm{CPC}$-fraction from $64 \pm 26$ to $88 \pm$ 46 cells per 1 million MNCs $(p=0.023) .17$ weeks of follow-up, the number of $\mathrm{CD} 45^{+} / \mathrm{CD} 34^{+} \mathrm{CPCs}$ decreased to $269 \pm 117$ cells per 1 million MNCs and the number of $\mathrm{CD} 45^{+} / \mathrm{CD} 133^{+}$CPCs decreased to $68 \pm$ 32 cells per 1 million MNCs, reaching nearly the level of onset measurement. In the nonexercise training group the number of CPCs remained stable from $t_{0}$ (two weeks after acute AMI) to five weeks and 17 weeks of follow-up. The number of $\mathrm{CD} 45^{+} / \mathrm{CD} 34^{+}$ cells counted $275 \pm 68$ cells per 1 million MNCs at $t_{0}$, $254 \pm 66$ cells per 1 million MNCs five weeks of follow-up and $268 \pm 69$ cells per 1 million MNCs 17 weeks of follow-up (Fig. $5 \mathrm{a}$ and Table 3). The number 
Table 3. Response to exercise training and traditionaly rehabilitation in patients with STEMI evaluated by ergometry, exercise echogardiography, exercise spiroergometry and BNP (brain natriuretic peptide).

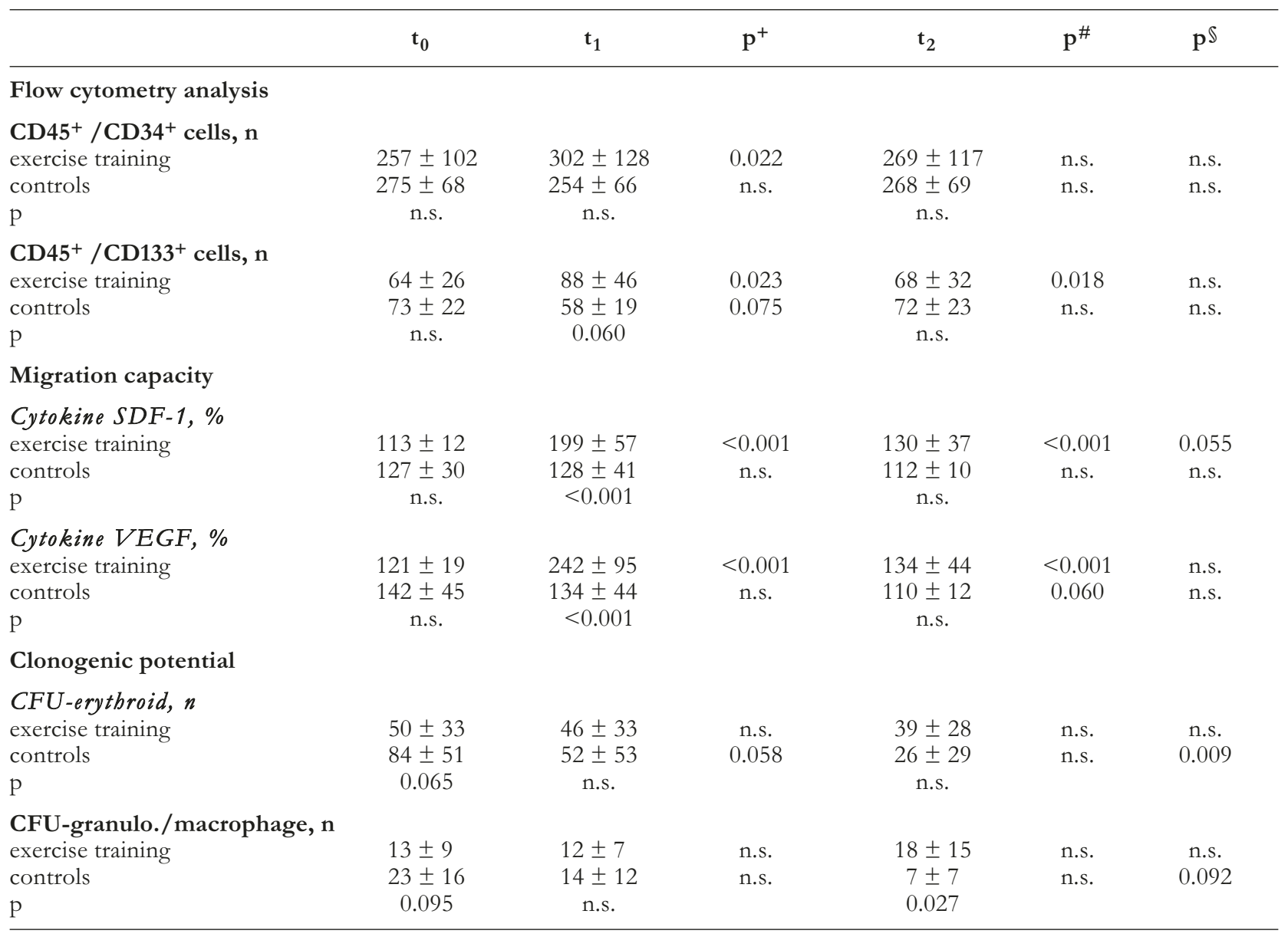

Data are shown as mean \pm SD.Amount of $\mathrm{CD} 45^{+} / \mathrm{CD} 34^{+}$cells and $\mathrm{CD} 45^{+} / \mathrm{CD} 133^{+}$cells are expressed as cells per $1 \mathrm{x} 10^{6}$ MNCs. Migration capacity is expressed in \% as relation of migrated cells toward the cytokines SDF-1 and VEGF in comparison to the migrated cells without chemokine. Colony forming unit is expressed as number of colonies per $1 \mathrm{x} 10^{5}$ seeded MNCs. Values are mean $\pm S D \cdot \mathrm{p}^{+}=\mathrm{t}_{0}$ vs. $\mathrm{t}_{1} ; \mathrm{p} \#=\mathrm{t}_{1}$ vs. $\mathrm{t}_{2} ; \mathrm{p} \rrbracket=\mathrm{t}_{0}$ vs. $\mathrm{t}_{2}$

of $\mathrm{CD}_{4} 5^{+} / \mathrm{CD} 133^{+}$cells was $73 \pm 22$, five weeks of follow-up $58 \pm 19$ and 17 weeks of follow-up $72 \pm 23$ cells per 1 million MNCs. In the exercise training group, the $\mathrm{CD} 45^{+} / \mathrm{CD} 133^{+} \mathrm{CPCs}$ was slightly increased at five weeks of follow-up (after the physical training) compared to the controls (Fig. $5 \mathrm{~b}$ and Table 3).

Effects of regular exercise training on CPC function: In order to assess the influence of regular exercise training on CPC function, the migration capacity of the CPCs was analyzed. Regular exercise training in patients with STEMI led to a significant enhancement of CPCs migration capacity after the three weeks lasting training program from $113 \pm 12$ to $199 \pm 57 \%(\mathrm{SDF}-$ 1 , in relation to control cells without cytokine, $\mathrm{p}<0.001$ ), and from $121 \pm 19 \%$ to $242 \pm 95 \%$ (VEGF, in relation to control cells without cytokine, $\mathrm{p}<0.001$ ), although this phenomenon had vanished by three months thereafter (Fig. 4 and 6 a, b). The CPCs migration capacity was significantly increased after the physical training $\left(t_{1}\right)$ in the exercise training group compared to the controls.

The improved ability of the CPCs to migrate in the exercise training group was accompanied by a stable number of colonies, as demonstrated by CFU-erythroid and CFU -granulocyte/ macrophage. In the non-exercise group after STEMI, the migration capacity revealed no increase over the investigated time, whereas the number of colonies in the clonogenic assays declined continuously after acute myocardial infarction from $23 \pm 16$ colonies before ET to $7 \pm 7$ colonies three months later in the CFU-GM assay and significantly from $84 \pm 51$ colonies before ET to $26 \pm$ 29 colonies three months later in the CFU-E assay (Table 3).

\section{Discussion}

In this prospective clinical trail, we assessed the effects of regular exercise training in patients with STEMI on clinical parameters (including BNP-level) and on the quantity and quality of CPCs. In patients with STEMI, regular symptom-limited exercise training over three weeks was able to (i) improve the clinical condition (NYHA-classification), (ii) increase the left ventricular ejection fraction at peak exercise, (iii) improve the cardiovascular capacity (exercise spiroergometry) and (iv) enhance the mobilization of blood-derived circulating 

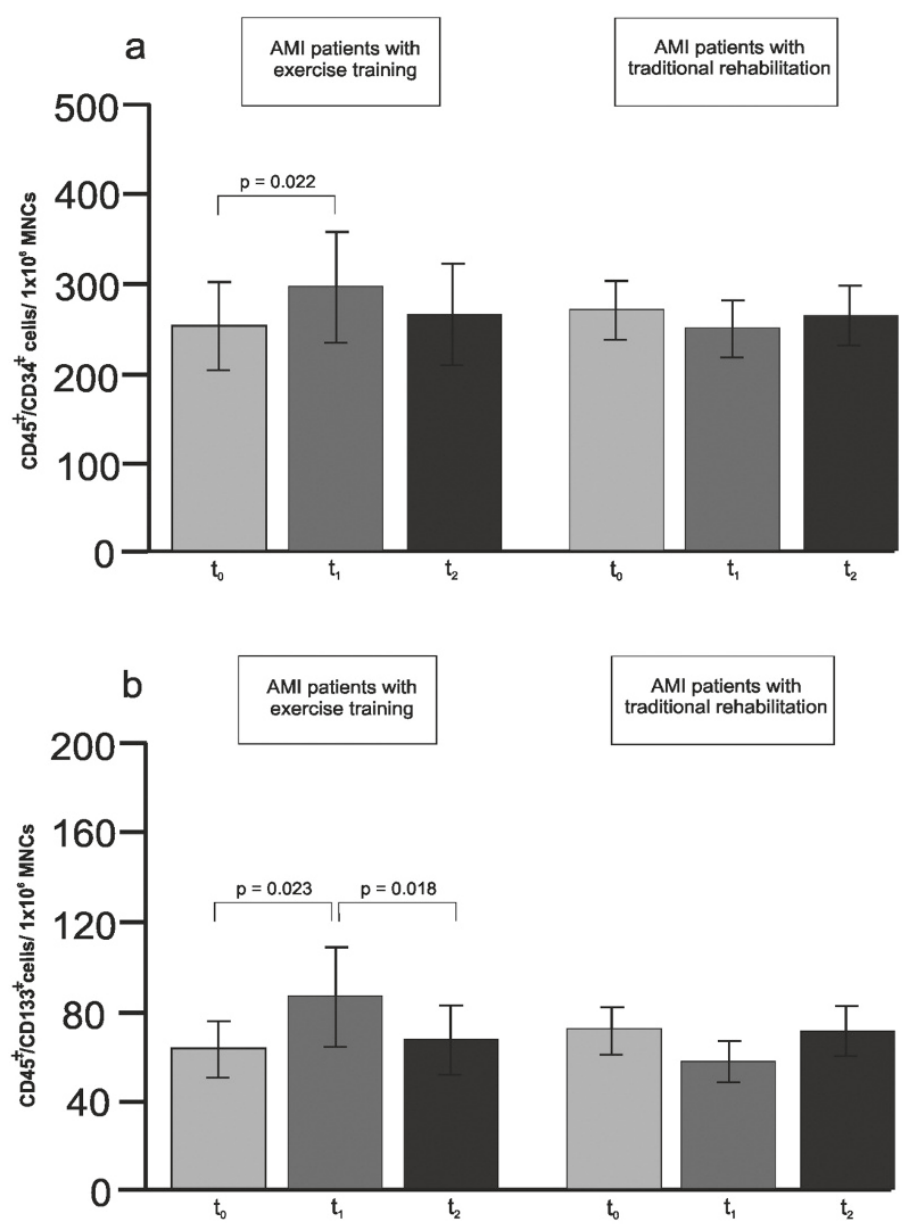

Fig. 5. Quantitative evaluation of $\mathrm{CD} 45^{+} / \mathrm{CD} 34^{+}$ cells (Fig. 5a) and CD $45^{+} / \mathrm{CD} 133^{+}$cells (Fig. 5b) by flow cytometry analysis. Patients with exercise training shows a temporarily increase of the CPCs between $t_{0}$ and $t_{1}$. In the control group (patients with traditional rehabilitation) were no differences observed. Values are expressed as total numbers of $\mathrm{CD} 45^{+} / \mathrm{CD} 4^{+}$cells, respectively $\mathrm{CD} 45^{+} / \mathrm{CD} 133^{+}$ cells, related to $1 \times 10^{6}$ MNCs. Values are mean \pm SD. $\mathrm{t}_{0}$, before exercise training; $\mathrm{t}_{1}$, after exercise training; $t_{2}, 3$ months after exercise training.

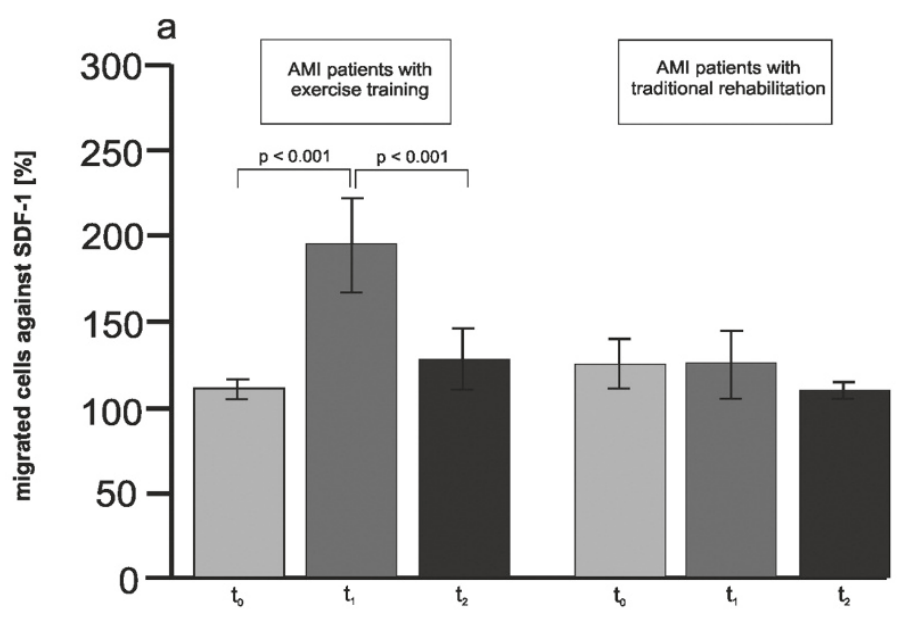

b

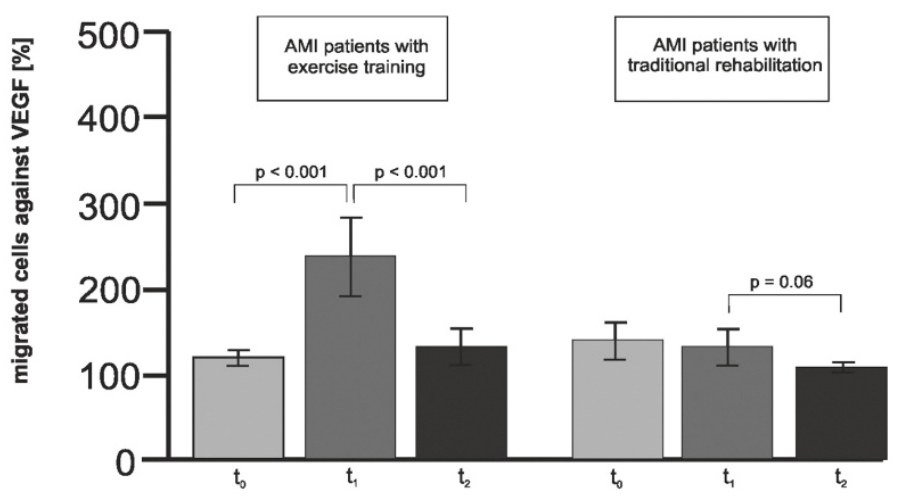

Fig. 6. Quantitative evaluation of migration capacity of CPCs in boyden chamber. Relative amount of migrated cells to SDF-1 (a) and VEGF (b) in comparison to cells without chemokines in blood samples of patients with STEMI and exercise training and patients with STEMI and traditional rehabilitation, blood samples were analyzed at 3 different time points. Values are expressed as \% of migrated cells without chemokine. Values are mean \pm SD. 
progenitor cells from bone marrow into peripheral blood, improve the migratory capacity and stabilize the clonogenic potential of the CPCs.

These data imply that regular symptom-limited exercise training suffices to increase the quantity and function of circulating progenitor cells. This finding is consistent with the hypothesis that an ischemic stimulus may trigger the release of CPCs from the bone marrow into the peripheral blood.

The development of new vessels in response to tissue ischemia constitutes a natural reaction intended to maintain adequate perfusion. This process was formerly believed to result from the sprouting of preexisting arteries rather than the formation of entirely new vessels. However, this traditional concept was shattered by the observations that operative hind limb ischemia induces a significant increase in circulating bone marrow-derived EPCs and that heterologous, homologous or autologous transplanted EPCs become incorporated into neovascularisation foci $[9,11$, $20,21]$. Such results from animal models have also been confirmed in clinical settings. An increase in EPCs and a possible participation in neovascularisation have both been demonstrated in patients with acute myocardial infarction [12, 22]. Clinical trials studying the intracoronary transplantation of $\mathrm{BM}$ stem / progenitor cells as well as BM-derived autologous circulating progenitor cells have also shown that these cells have the potential to improve the function of the myocardium after acute ischemic injury [23-27]. Nevertheless, many questions remain to be answered.

Does a regular exercise training have any effect on the number and function of circulating progenitor cells after myocardial infarction?

Circulating progenitor cells as $\mathrm{CD} 45^{+} / \mathrm{CD} 34^{+}$and $\mathrm{CD} 45^{+} / \mathrm{CD}_{133^{+}}$stem cells were investigated, both are primitive bone marrow cells that have the capacity to proliferate, migrate, and differentiate into various mature cell types $[28,29]$. These bone marrow-derived circulating progenitor cells express unique surface markers, as CD34 and the early hematopoetic cell marker CD133 (AC133) [30, 31]. Tissue ischemia was found to mobilize endothelial progenitor cells into the peripheral blood and to contribute to neovascularisation in an animal model [11]. In addition, human BM-CPCs have been shown to be significantly increased in patients after acute myocardial infarction (AMI) [12] and to differentiate into cardiac myocytes, endothelial cells and smooth muscle cells following AMI [32]. Experimental studies suggested that BM-CPCs may contribute to the regeneration of infarcted myocardium [33] [34] and improve neovascularization of ischaemic myocardium [35-38]. However, the function of early haematopoietic stem cell marker CD133 is still unknown. Using CD133 expression to define a very early subset of progenitor cells, Peichev et al. [31] isolated a CD133 ${ }^{+}$subpopulation of cells, which were able to differentiate into mature endothelial cells.

This present study is the first report showing that regular symptom-limited exercise training is sufficient to trigger a time-dependent increase in circulating progenitor cells and their function in patients who had previously suffered an acute myocardial infarction.
Regular exercise training leds to a significant increase in circulating progenitor cells $\left(\mathrm{CD} 34^{+}\right.$cells, respectively $\mathrm{CD} 133^{+}$cells). This augmentation in CPCs is comparable with the response to other therapeutic stimuli that increase CPCs, such as a four week long statin therapy [39] or VEGF-gene therapy [10, 40].

The transient increase in circulating progenitor cells after regular symptom-limited (ischemic and /or subischemic) exercise training reached a maximum after the exercise training, but did not persist up until three months after the regular exercise training. This finding extends our knowledge about the long-term effect of rehabilitation training programs on the changes in circulating progenitor cells. Laufs and colleagues described a significant increase in circulating progenitor cells after a 4 week, non-controlled rehabilitation training program in patients with stable coronary artery disease without exercise-induced ischemia [41]. In that trial it was speculated that asymptomatic tissue ischemia leads to an increase in vasculogenic cytokines, in the same way that symptomatic tissue ischemia does.

It is important to note here that an increase in CPCs is associated with significant increases in both $\mathrm{CD}^{+}{ }^{+}$cells and $\mathrm{CD} 133^{+}$cells. This observation suggests that the response of the bone marrow to episodes of ischemia is not restricted to a specific cell type release, but is much rather a complex reaction where various progenitor cell populations and leukocyte subtypes become involved.

Not only is the quantity of circulation progenitor cells is altered, but their function is also modified by ischemic conditions and therapeutic interventions [42]. Migration of CPCs to ischemic tissue is believed to play a major role in the growth of new bloodvessels. Migration is essential for the ability of stem / progenitor cells to invade ischemic tissue. SDF-1 and VEGF are both profoundly upregulated in hypoxic tissue and may therefore represent physiologically relevant chemoattractants for the recruitment of circulating progenitor cells to ischemia sites [43, 44]. Indeed, intramuscular injection of SDF-1 has recently been shown to increase the number of incorporated endothelial progenitor cells and to improve neovascularisation in vivo [45].

In the present study, a migration assay was performed to investigate the ability of CPCs to migrate into ischemic tissue. The Boyden Chamber simulates the capacity of circulating progenitor cells to migrate to a chemotaxin such as VEGF or SDF-1 in patients with STEMI. This finding is consistent with the notion that both VEGF and SDF-1, which were differentially regulated during ischemic training, are involved primarily in altering the functional characteristics of CPCs. The result of the phenotypic analysis was not in accordance with a larger number of hematopoietic colonies obtained from peripheral blood mononuclear cells of patients with acute myocardial infarction performing regular exercise training, instead the number of the colonies remained stable over the investigated time. In patients with acute myocardial infarction performing no rehabilitation a continuous decrease in the number of hematopoietic colonies was assessed. This is in accordance with Massa et al.[46], demonstrating a 
continuous decline at 24 hours and 7 days with respect to admission with acute myocardial infarction. We suggest that immediately after acute myocardial infarction the number of colonies goes up, but then decline continuously. If regular exercise training (rehabilitation) is performed after acute myocardial infarction the decline of the number of colonies is delayed or even prevented. Improvement of clinical and hemodynamic parameters after regular exercise-training ET improves the quality of life in both men and women with moderate, chronic heart failure [47]. In a recent meta analysis by Smart and Marwick looking at patients with stable heart failure, ET was found to be associated with a reduction in cardiorespiratory symptoms and an improved functional capacity [48]. We have shown in our study an improved clinical condition (depicted in NYHA classification) and a decreased BNP-level directly after exercise training and three months thereafter.

Some clinical studies suggest that ET improves cardiac output by consistently increasing exercise capacity in heart failure [49] [50]. Likewise, we also found a significantly improved exercise capacity in the ET group, probably because of the increased left ventricular ejection fraction at peak exercise and the enhanced maximum oxygen uptake $\left(\mathrm{VO}_{2} \max \right)$ after a regular three week-long ET.

ET in chronic heart failure reduces catecholamines and vascular peripheral resistance while modulating heart rate variability and the baroreflex gain [51]. In a multicentre, randomised controlled clinical study (ELVD) in patients with a first Qwave myocardial infarction [52], regional wall motion abnormalities and endsystolic volume both decreased 6 months after the ET. In that study it was suggested that an enhanced contractile performance predominantly contributed to the improved left ventricular function in their patients who showed an ejection fraction of below $40 \%$.

Our findings show a significant increase in left ventricular ejection fraction at peak exercise in the bicycle echocardiography after ET, similar to the data of Giannuzzi et al., but we did not find an increase in the left ventricular ejection fraction at rest. This difference may have arisen because of the lower left ventricular ejection fraction and the longer exercise program period (6 months) that was evident in the ELVD study.

On the basis of the findings of Giannuzzi et al. [52], it is tempting to speculate that regular exercise training may decrease endsystolic volume and regional wall motion abnormalities by bringing about beneficial changes in the autonomic balance and / or baroreflex gain. This is in line with an attenuation of the vasoconstrictor influence (mainly due to reduced sympathetic activity) and an increase in vagal tone [51].

Regular exercise training improved myocardial perfusion in stable coronary artery disease [53]. In acute myocardial infarction, long-term exercise training improved left ventricular ejection fraction evaluated by radionuclide ventriculography [54]. Furthermore, early post-infarction cardiac rehabilitation improved the cardiorespiratory fitness, with direct measurement of maximal oxygen uptake $\left(\mathrm{VO}_{2} \max \right)$ [55].

In the present study, we demonstrate an increased exercise capacity, an improved cardiac function and a better cardiorespiratory condition in patients with acute myocardial infarction performing regular exercise training. In an animal model physical training increases endothelial progenitor cells, inhibits neointimal formation and enhances angiogenesis [41]. One mechanism of repair by which physical training may improve in human cardiac function after myocardial infarction, is considered to be the mobilization of bone marrow-derived progenitor cells homing into the damaged tissue area, where they induced neovascularisation [56] [57]. Homing of the progenitor cells can be improved by the chemokine stromal cell-derived factor 1 (SDF-1), which is intrinsically produced by the myocardium after myocardial infarction. As recently shown, the intramyocardial delivery of SDF-1 increases the homing of c-kit+ stem cells [58]. The beneficial effect of regular exercise training on myocardial perfusion has not been well established in humans. However, increased myocardial perfusion was demonstrated after symptom-limited exercise training after acute myocardial infarction [59] [60]. Mechanisms that promote enhanced myocardial perfusion include significant release of bone marrow-derived progenitor cells into circulation, as observed in our study. In addition, paracrine angiogenic factors, such as vascular endothelial growth factor are released after physical training and may increase neovascularisation in ischemic tissue [41] [61]. Enhanced neovascularisation may serve as one important mechanism facilitating reduction of infarct size after myocardial infarction.

In this first prospective clinical study, we were able to confirm the efficacy of a regular three week-long (15 times) symptom-limited (ischemia) exercise training in increasing both the cardiac function and number of CPCs amongst patients with STEMI. The following major conclusions can be drawn from our findings: (i) local tissue ischemia induced by symptom-limited exercise training enhance the mobilization of regenerative progenitor cells from bone marrow into peripheral blood, (ii) ischemia may be involved in the regulation of the migration capacity of CPCs and (iii) enhanced mobilization and increase migration capacity of CPCs are associated with improved cardiac function and cardiorespiratory condition. Thus, early short term exercise training has beneficial effects for the rehabilitation of patients with STEMI.

Acknowledgments: We thank Andrea Tüffers and Evelyn Chetolin for their excellent technical assistance.

\section{REFERENCES}

1. Morris JN, Everitt MG, Pollard R, Chave SP, Semmence AM. Vigorous exercise in leisure-time: protection against coronary heart disease. Lancet 1980; 2: 1207- 1210.

2. Paffenbarger RS Jr, Hyde RT, Wing AL, Hsieh CC. Physical activity, all-cause mortality, and longevity of college alumni. N Eng J Med. 1986; 314: 605-613.

3. Sesso HD, Paffenbarger RS, Lee I-M. Physical activitiy and coronary heart disease in men; the Harvard alumni health study. Circulation 2000; 102: 975-980.

4. Paul D. Thompson. Exercise prescription and proscription for patients with coronary artery disease. Circulation 2005; 112: 2354-2363. 
5. Sebrechts CP, Klein JL, Ahnve S, Froelicher VF, Ashburn VL. Myocardial perfusion changes following 1 year of exercise training assessed by thallium-201 circumferential count profiles. Am Heart J. 1986; 112: 1217-1226.

6. Heringlake M, Kox T, Poeling J et al. The effects of physical exercise on plasma levels of relaxin, NTpro ANP, and NTproBNP in patients with ischemic heart disease. Eur J Med Res. 2009; 17;14(3): 106-112.

7. Hambrecht R, Wolf A, Gielen S, et al. Effect of exercise on coronary endothelial function in patients with coronary artery disease. N Eng J Med. 2000; 342: 454-460.

8. Aicher A, Heeschen C, Mildner-Rihm C, et al. Essential role of endothelial nitric oxide synthase for mobilization of stem and progenitor cells. Nat Med 2003, 9:1370-1376.

9. Takahashi T, Kalka C, Masuda H, et al. Ischemia- and cytokine-induced mobilization of bone marrow-derived endothelial progenitor cells for neovascularization. Nat Med. 1999; 5: 434- 438.

10. Asahara T, Takahashi T, Masuda H. VEGF contributes to postnatal neovascularization by mobilizing bone-marrow endothelial progenitor cells. EMBO J. 1999; 18: 3964-3972.

11. Asahara T., Masuda H, Takahashi T, et al. Bone marrow origin of endothelial progenitor cells responsible for postnatal vasculogenesis in physiological and pathological neovascularization. Circ Res. 1999; 85:221-228.

12 Shintani S, Murohara T, Ikeda H, et al. Mobilization of endothelial progenitor cells in patients with acute myocardial infarction. Circulation. 2001 ; 103: 2776-2779.

13. Yeh ET, Zhang S, Wu HD, Korbling M, Willerson JT, Estrov Z. Transdifferan-tiation of human peripheral blood $\mathrm{CD}_{3} 4^{+}$enriched cell population into cardiomyocytes, endothelial cells and smooth muscle cells in vivo. Circulation. 2003; $108: 2070-2073$

14. Vasa M., Fichtlscherer S., Aicher A., et al. Number and migratory activity of circulating endothelial progenitor cells inversely correlate with risk factors for coronary artery disease. Circ Res. 2001; 89: E1-7.

15. Volker A, Lenk K, Linke A, et al. Increase of circulating endothelial progenitor cells in patients with coronary artery disease after exercise-induced ischemia. Arterioscler Thromb Vasc Biol. 2004; 24: 684-690.

16. Gysan DB, Heinzler R, Schmidt K. [Primary results and long-term outcome of an ambulatory, cardiac rehabilitation model (phase II) after myocardial infarct, dilatation treatment and heart operation] Z Kardiol. 1997; 86:691-702.

17. Schonstedt S, Beckmann S, Disselhoff W, Russmann B. [Experiences with ambulatory cardiologic phase II rehabilitation] Herz. 1999; 24 Suppl 1:3-8.

18. Sutherland D.R., Anderson L., Keeney M., Nayar R., Chin-Yee I. The ISHAGE guidelines for $\mathrm{CD} 34^{+}$cell determinaiton by flow cytometry. J. Hematotherapy, 1996; 5: 213-226.

19. Borowitz MJ, Guenther KL, Schults KE, Stelzer GT. Immunophenotyping of acute leukemia by flow cytometric analysis. Use of CD45 and right-angle light scatter to gate on leukemic blasts in three-color analysis. Am J Clin Pathol. 1993, 100:534- 540.

20. Crosby JR, Kamiski WE, Schatteman G, et al. Endothelial cells of hematopoietic origin make a significant contribution to adult blood vessel formation. Circ Res. 2000; 87 : 728-730.

21. Isner JM, Asahara T. Angiogenesis and vasculogenesis as therapeutic strategies for postnatal neovascularization. J Clin Invest. 1999; 103:1231-1236.

22. Lin Y, Weisdorf DJ, Solovey A, Hebbel RP. Origins of circulating endothelial cells and endothelial outgrowth from blood. Eur J Clin Invest. 2000; 278: H1042-H1048.

23. Strauer BE, Brehm M, Zeus T, et al. Repair of infarcted myocardium by autologous intracoronary mononuclear bone marrow cell transplantation in humans. Circulation 2002; 106: 1913-1918.
24. Meyer G, Wollert K, Drexler H. Stem cell therapy: a new perspective in the treatment of patients with acute myocardial infarction. Eur J Med Res. 2006; 11;(10): 43946.

25. Wollert KC, Meyer GP, Lotz J, et al. Intracoronary autologous bone marrow cell transfer after myocardial infarction: the BOOST randomised controlled clinical trial. Lancet 2004; 364: 141- 148

26. Schachinger V, Erbs S, Elsasser A, et al.. Inracoronary bone marrow-derived progenitor cells in acute myocardial infarction. N.Engl J Med 2006; 355: 1210-1221

27. Assmus B, Honold J, Schachinger V, et al. Transcoronary transplantation of progenitor cells after myocardial infarction. N Engl J Med 2006; 355: 1222-1232.

28. Luttun A, Carmeliet G, Carmeliet P. Vascular progenitors: from biology to treatment. Trends Cardiovasc Med 2002; 12:88-96.

29. Fritzenwanger M, Lorenz F, Jung C, et al. Differential number of $\mathrm{CD}_{34}+\mathrm{CD} 133^{+}$and $\mathrm{CD} 34+/ \mathrm{CD} 133^{+}$cells in peripheral blood of patients with congestive heart failure. Eur J Med Res. 2009; 14;(3): 113-117.

30. Yin AH, Miraglia S, Zanjani ED, et al. AC133, a novel marker for human haematopoietic stem and progenitor cells. Blood 1997; 90:5002-5012.

31. Peichev M, Naiyer AJ, Pereira D, et al. Expression of VEGFR-2 and AC133 by circulating human CD34+ cells identifies a population of functional endothelial precursors. Blood 2000; 95:952-958.

32. Yeh ETH, Zhang S, Wu HD, Körbling M, Willerson JT, Estrov Z. Transdifferentiation of human peripheral blood $\mathrm{CD}_{3} 4^{+}$enriched cell population into cardiomyocytes, endothelial cells and smooth muscle cells in vivo. Circulation 2003; 108:2070-2073.

33. Orlic D, Kajstura J, Chimenti S, et al. Bone marrow cells regenerate infarcted myocardium. Nature 2001; 410:701705 .

34. Orlic D, Kajstura J, Chimenti S, et al. Mobilised bone marrow cells repair the infarcted heart, improving function and survival. Proc Natl Acad Sci USA 2001; 98:10344-10349.

35. Kawamoto A, Gwon HC, Iwaguro H, et al.Therapeutic potential of ex vivo expanded endothelial progenitor cells for myocardial ischemia. Circulation 2001; 103: 634637.

36. Kawamoto A, Tkebuchava T, Yamaguchi J, et al. Intramyocardial transplanta-tion of autologous endothelial progenitor cells for therapeutic neovascularization of myocardial ischaemia. Circulation 2003; 107:461-468.

37. Kocher AA, Schuster MD, Szabolcs MJ, et al. Neovascularization of ischaemic myocardium by human bone marrow-derived angioblasts prevents cardiomyocyte apoptosis, reduces remodeling and improves cardiac function. Nat Med 2001; 7:430-436.

38. Fuchs S, Baffour R, Zhou YF, et al. Transendocardial delivery of autologous bone marrow enhances collateral perfusion and regional function in pigs with chronic experimental myocardial ischaemia. J Am Coll Cardiol 2001; 37:1726-1732.

39. Vasa M, Fichtlsscherer S, Adler K, Aicher A, MartinH, Zeiher A, Dimmeler S. Increase in circulating endothelial progenitor cells in patients by statin therapy in patients with stable coronary artery disease. Circulation 2001; 103: r21-r26.

40. Kalka C, Tehrani H, Laudenberg B, Vale PR, Isner JM, Asahara T, Symes JF. VEGF gene transfer mobilizes endothelial progenitor cells in patients with inoperable coronary disease. Ann Thorac Surg 2000; 70: 829-834.

41. Laufs U, Werner N, Link A, et al. Physical training increases endothelial progenitor cell, inhibits neointima formation, and enhances angiogenesis. Circulation 2004; 109: $220-226$ 
42. Heeschen C, Lehmann R, Honold J, et al. Profoundly reduced neovascularization capacity of bone marrow mononuclear cells derived from patients with chronic ischemic heart disease. Circulation. 2004; 109: 1615-1622.

43. Lee SH, Wolf PL, Escudero R, Deutsch R, Jamieson SW, Thistlethwaite PA. Early expression of angiogenesis factors in acute myocardial ischemia and infarction. $\mathrm{N}$ Eng J Med 2000; 342: 626-633

44. Pillarisetti K, Gupta SK. Cloning and relative expression analysis of rat stromal cell derived factor-1 (SDF-1)1: SDF-1 alpha mRNA is selectively induced in rat model of myocardial infarction. Inflammation. 2001; 25: 293-300

45. Yamaguchi J, Kusano KF, Masuo Oet al. Stromal cell-derived factor-1 effects on ex vivo expanded endothelial progenitor cell recruitment for ischemic neovascularization. Circulation 2003; 107: 1322-1328.

46. Massa M, Rosti V, Ferrario M, et al. Increased circulating hematopoietic and endothelial progenitor cells in the early phase of acute myocardial infarction. Blood. 2005; 105: 199-206.

47. Tyni-Lenne R, Gordon A, Europe E, Jansson E, Sylven C. Exercise based rehabilitation improves skeletal muscle capacity, exercise tolerance, and quality of life in both women and men with chronic heart failure. J Card Fail. 1998; 4: 9-17.

48. Smart N, Marwick TH. Exercise training for patients with heart failure: a systematic review of factors that improve mortality and morbidity. Am J Med. 2004; 116: 693-796.

49. Cheetham C, Green D, Collis J, Dembo L, O'Driscoll G. Effect of aerobic and resistance exercise on central hemodynamic responses in severe chronic heart failure. J Appl Physiol. 2002; 93: 175-180.

50. Pina IL, Apstein CS, Balady GJ, et al; American Heart Association Committee on exercise, rehabilitation, and prevention. Exercise and heart failure: a statement from the American Heart Association Committee on Exercise, Rehabilitation, and Prevention. Circulation. 2003; 107: 12101225.

51. Coats AJ, Adamopoulos S, Radaelli A, et al. Controlled trial of physical training in chronic heart failure : exercise performance, hemodynamics, ventilation, and autonomic function. Circulation. 1992; 85: 2119-2131.

52. Giannuzzi P, Temporelli PL, Corra U, Gattone M, Giordano A, Tavazzi L. Attenuation of unfavorable remodeling by exercise training in postinfarction patients with left ventricular dysfunction. Results of the Exercise in Left Ventricu-lar Dysfunction (ELVD) Trial. Circulation 1997; 96: 17901797

53. Schuler G, Hambrecht R, Schlierf G, Grunze M, Methfessel S, Hauer K, Kübler W. Myocardial perfusion and regression of coronary artery disease in patients on a regimen of intensive physical exercise and low fat diet. J Am Coll Cardiol. 1992; 19:34-42.
54. Barletta GA, Fattirolli F, Bisi G, et al. Short term responses to cardiac rehabilitation after acute myocardial infarction. Cardiac function evaluation before and after physical training at rest and during stress test. Eur Heart J. 1983; 4:761 772 .

55. Dressendorfer RH, Franklin BA, Cameron JL, Trahan KJ, Gordon S, Timmis GC. Exercise training frequency in early postinfarction cardiac rehabilitation. Influence on aerobic conditioning. J Cardiopulm Rehabil. 1995; 15:269-276.

56. Ohtsuka M, Takano H, Zou Y, et al. Cytokine therapy prevents left ventricular remodeling and dysfunction after myocardial infarction through neovascularization. FASEB J. 2004; 18:851-853.

57. Ohki Y, Heissig B, Sato Y, et al. Granulocyte colonystimulating factor promotes neovascularization by releasing vascular endothelial growth factor from neutrophils. FASEB J. 2005; 19:2005-2007.

58. Askari AT, Unzek S, Popovic ZB, et al. Effect of stromalcell-derived factor 1 on stemcell homing and tissue regeneration in ischaemic cardiomyopathy. Lancet. 2003; 362:697-703.

59. Gunning MG, Walker J, Eastick S, Bomanji JB, Ell PJ, Walker JM. Exercise training following myocardial infarction improves myocardial perfusion assessed by thallium201 scintigraphy. Int J Cardiol. 2002; 84:233-239.

60. Hung J, Gordon EP, Houston N, Haskell WL, Goris ML, DeBusk RF. Changes in rest and exercise myocardial perfusion and left ventricular function 3 to 26 weeks after clinically uncomplicated acute myocardial infarction: effects of exercise training. Am J Cardiol. 1984; 54:943-950.

61. Yoon YS, Johnson IA, Park JS, Diaz L, Losordo DW. Therapeutic myocardial angiogenesis with vascular endothelial growth factors. Mol Cell Biochem. 2004; 264:6374.

Received: June 25, 2009 / Accepted: June 29, 2009

Address for correspondence:

Michael Brehm, MD

Department of Internal Medicine

Division of Cardiology, Pneumology and Angiology

Heinrich-Heine-University

Moorenstr. 5

40225 Düsseldorf

Germany

Tel. $\quad+49$ (0) 2118118800

Fax +49(0) 2118119520

E-mail: brehm@med.uni-duesseldorf.de 